\title{
Second-generation proteasome inhibitor carfilzomib sensitizes neuroblastoma cells to doxorubicin-induced apoptosis
}

\author{
Shan Guan ${ }^{1,2}$, Yanling Zhao ${ }^{2}$, Jiaxiong Lu²,3, Yang $\mathbf{Y u}^{2,4}$, Wenjing Sun ${ }^{2,4}$, Xinfang \\ $\mathbf{M a o}^{1,2}$, Zhenghu Chen ${ }^{2,3}$, Xin $\mathrm{Xu}^{2}$, Jessie Pan ${ }^{2}$, Surong Sun ${ }^{1}$, Jianhua Yang ${ }^{2}$ \\ ${ }^{1}$ Xinjiang Key Laboratory of Biological Resources and Genetic Engineering, College of Life Science and Technology, Xinjiang \\ University, Urumqi 830046, Xinjiang, China \\ ${ }^{2}$ Texas Children's Cancer Center, Department of Pediatrics, Dan L. Duncan Cancer Center, Baylor College of Medicine, \\ Houston, TX 77030, USA \\ ${ }^{3}$ Department of Ophthalmology, Shanghai Tenth People's Hospital, Tongji University School of Medicine, Shanghai 200072, \\ China \\ ${ }^{4}$ Labratory of Medical Genetics, Harbin Medical University, Harbin, Heilongjiang 150081, China \\ Correspondence to: Surong Sun, email: sr_sun2005@163.com \\ Jianhua Yang, email: jianhuay@bcm.edu
}

Keywords: neuroblastoma, proteasome inhibitor, carfilzomib, chemotherapy, doxorubicin

Received: July 20, 2016

Accepted: September 22, 2016

Published: October 04, 2016

\section{ABSTRACT}

Neuroblastoma (NB), which accounts for about $15 \%$ of cancer-related mortality in children, is the most common extracranial malignant neoplasm in children. Elevated level of proteasome activity promotes cancer development and the inhibition of proteasome activity is a promising strategy for cancer treatment. Therefore, targeting proteasome by small molecule inhibitors may be a viable option for NB therapy. Here in this study, we show that a novel proteasome inhibitor Carfilzomib (CFZ) exerts anti-tumor effect on NB. CFZ caused decreased cell viability and attenuated colony formation ability of a subset of NB cell lines. CFZ induced cell apoptosis in NB cells. Moreover, CFZ enhanced the cytotoxic effect of doxorubicin (Dox) on NB cells and Dox-induced p38 and JNK phosphorylation. In addition, CFZ inhibited Dox-induced NF-KB activation by stabilizing the protein level of IKBa. Furthermore, CFZ induced apoptosis and augmented Dox-induced apoptosis in NB tumor cells in orthotopic xenograft mouse models. In summary, our study suggests that proteasome is a therapeutic target in NB and proteasome inhibition by CFZ is a potential therapeutic strategy for treating NB patients.

\section{INTRODUCTION}

Ranking as the most common childhood extracranial neoplasm, neuroblastoma (NB) accounts for about $15 \%$ of cancer-related deaths in children [1-3]. With the collaborations of cooperative group trials in US and around the world, low- and intermediate-risk NB have demonstrated good outcomes. Nevertheless, overall survival rate for high-risk NB remains poor. Thus, novel therapies for NB, especially high-risk NB, are urgently needed.

Proteasome, which plays a crucial role in cellular homeostasis, participates in intracellular protein degradation via ubiquitin/proteasome pathway [4-9]. The inhibition of proteasome functions, especially selective inhibition of proteasome's chymotrypsin-like subunits, would promote cell cycle arrest, apoptosis and cell death with minimal side-effects on total cellular protein turnover, which in turn helps to substantiate proteasome as an optimal chemotherapeutic target [10-15].

The transcription/nuclear factor kappa B (NF- $\kappa \mathrm{B})$, is involved in the regulation of immune/inflammatory responses, proliferation, and tumorigenesis [16-18]. Elevated NF- $\mathrm{KB}$ activation in cancer cells promotes tumor survival and progression [19-21]. In NB, the upregulation of NF- $\mathrm{\kappa B}$ has been shown to accelerate tumor growth and promote cancer cell survival [1, 19, 22, 23]. The blockade of NF- $\mathrm{kB}$ activation in cancer cells has been suggested to be a potential therapeutic strategy [24, 25]. The nuclear factor of kappa light polypeptide gene 
enhancer in B-cells inhibitor, alpha $(\mathrm{I} \kappa \mathrm{B} \alpha)$ is one member of a family of cellular proteins that function to inhibit the NF- $\kappa \mathrm{B}$ transcription factor. Since the ubiquitination and proteasomal degradation of $\mathrm{I} \kappa \mathrm{B} \alpha$ is required for $\mathrm{NF}-\kappa \mathrm{B}$ activation, and proteasome inhibition augments chemotherapeutic response by inhibiting I $\kappa \mathrm{B} \alpha$ degradation and subsequently inhibiting NF- $\mathrm{B}$ activation [10-15].

Two FDA (US Food and Drug Administration)approved proteasome inhibitors, Bortezomib (for treating multiple myeloma) and Ixazomib (for treating relapsed/ refractory myeloma, in combination with lenalidomide and dexamethasone), demonstrate significant anti-tumor effects majorly via blocking the activation of NF- $\kappa \mathrm{B}$ pathway [19, 26-29], and are regarded as promising antiNB regimen [26]. However, Bortezomib failed to produce objective responses in vivo on chronic lymphocytic leukemia and resulted in severe cytotoxicities to normal tissue [30]. And despite proteasome inhibitors being highly active, resistance is commonly observed [31, 32]. Therefore, novel therapeutic agents with improved efficacy need to be developed.

Carfilzomib (CFZ) is a novel proteasome inhibitor that has already been approved by the FDA for treating the relapsed and refractory multiple myeloma in July of 2012 [33-36]. Prior studies demonstrated that CFZ irreversibly inhibits $26 \mathrm{~S}$ proteasome activity and efficiently stabilize I $\kappa \mathrm{B} \alpha$ by inhibiting its degradation, subsequently inhibiting $\mathrm{NF}-\kappa \mathrm{B}$ activation and inducing apoptosis pathway [3739]. In addition, CFZ activated the members of MAPK family, including the stress-activated kinases p38, JNK, and ERK1/2 in leukemia/lymphoma, lung cancer [40], etc. Herein, we evaluate the cytotoxic effects of CFZ on NB cells. Our results demonstrate that CFZ induced apoptosis and enhanced doxorubicin (Dox)-induced apoptosis through inhibiting the NF- $\mathrm{KB}$ activation and activating $\mathrm{p} 38$ and JNK pathway in NB. Our studies suggest that novel proteasome inhibitor $\mathrm{CFZ}$ might be a potential therapeutic agent for NB patients.

\section{RESULTS}

\section{Proteasome inhibitor CFZ exhibits cytotoxic effect on NB cells}

To determine the potential cytotoxic effect of CFZ on NB cells, the CCK-8 assay was measured on six NB cell lines, including three N-myc amplified cell lines (IMR-32, NB-19, NGP) and three N-myc non-amplified cell lines (LA-N-6, SH-SY5Y, SK-N-AS) (Figure 1). The cell viabilities of all cell lines tested were greatly reduced with increasing concentrations of $\mathrm{CFZ}$ after being treated for $72 \mathrm{~h}$ (Figure 1A). The IC50s of CFZ in all six cell lines were calculated, ranged from $3.31 \mathrm{nM}$ to $48.64 \mathrm{nM}$ (Figure 1A). Our results indicate that CFZ inhibits cell growth in a dose-dependent manner in NB cell lines. In addition, the cytotoxic effect of CFZ in NB cells was further confirmed by cell morphology change after the treatment (Figure 1B).

\section{CFZ inhibits anchorage-independent growth of NB cells}

The anchorage-independent growth ability in soft agar is one of the characteristics of cancer cells. To evaluate whether CFZ could inhibit the anchorageindependent growth of NB cells, soft agar assays were performed. In all six cell lines, including IMR-32, NB19, NGP, LA-N-6, SH-SY5Y, and SK-N-AS, a significant decrease in ability to form colonies were observed after CFZ treatment $(0.025 \mu \mathrm{M}, 0.05 \mu \mathrm{M})$, compared with vehicle-treated control (Figure 2A). The quantitative analysis also revealed the decreased colony numbers in CFZ treated cell lines (Figure 2B). Our results indicate that CFZ greatly attenuate anchorage-independent NB cell growth (Figure 2A and 2B).

\section{CFZ induces apoptosis in NB cells}

CFZ has been reported to induce apoptosis in a variety of tumor types, such as lung cancer and chronic lymphocytic leukemia [41]. Consistent with these reports, we found that CFZ treatment caused obvious Caspase 3 and PARP cleavage in NB cells tested (Figure 3), indicating CFZ induces apoptosis in NB cells. However, we noticed that two N-myc amplified cell lines NGP and NB-19 were more resistant to CFZ treatment compared to other NB cell lines tested (Figure 3 ).

\section{CFZ enhances the cytotoxic effect of Dox on NB cells}

Since monotherapies may result in the development of cancer chemo-resistance, the better strategies in attacking them might be combination therapy. We then evaluated the combination effects of CFZ and the conventional anti-NB chemotherapy drug Dox on a panel of six NB cell lines: IMR-32, NB-19, NGP, LA-N-6, SHSY5Y, and SK-N-AS. We observed enhanced cytotoxic effects on NB cells when cells were treated with CFZ in combination with Dox (Figure 4A). The combination treatment of CFZ and Dox also caused increased Caspase 3 and PARP cleavages compared to Dox or CFZ treatment alone (Figure 4B). These results demonstrate that CFZ greatly enhanced Dox-induced apoptosis in all NB cell lines.

\section{CFZ inhibits Dox-induced IкB $\alpha$ degradation and enhances Dox-induced p38 and JNK phosphorylation in NB cells}

The NF- $\kappa \mathrm{B}$ transcription factor induces the expression of a wide variety of genes important for cellular 
proliferation and survival, as well as inflammation and angiogenesis in NB $[17,21,42]$. Proteasome inhibition is a well-established approach which interferes with the $\mathrm{NF}-\kappa \mathrm{B}$ pathway by stabilizing I $\kappa \mathrm{B} \alpha$. Therefore, in order to determine the mechanism of CFZ's cytotoxic effect on NB, we utilized immunoblotting analysis to test the expression of $\mathrm{I} \kappa \mathrm{B} \alpha$ with single Dox (a strong NF- $\kappa \mathrm{B}$ inducer) or Dox and CFZ combination treatment in a panel of six NB cell lines. Our data indicate that CFZ inhibited the Dox-induced $\mathrm{I} \kappa \mathrm{B} \alpha$ degradation in all six cell lines tested (Figure 5). In addition, CFZ enhanced Dox-induced p38 and JNK phosphorylation (Figure 5). Together, our results indicate that CFZ may promote Dox-induced apoptosis by both enhancing p38 and JNK activation, and inhibiting NF- $\mathrm{B}$ activation through blocking $\mathrm{I} \kappa \mathrm{B} \alpha$ degradation.

\section{CFZ induces apoptosis in vivo}

An orthotopic xenograft NB mouse model was utilized to test whether CFZ could induce apoptosis in vivo. Luciferase-transduced SH-SY5Y cells were surgically injected into the left renal capsule of nude mice. Five weeks after injection, tumor formation were detected by bioluminescent imaging. Mice were then randomly divided into two groups and treated with either dimethylsulfoxide (DMSO) (carrier control) or CFZ (intraperitoneally injected $7.2 \mathrm{mg} / \mathrm{kg}$ daily for 3 days). Then, tumors from the mice treated with CFZ and control were harvested and analyzed for apoptotic effectors by immunoblotting analysis. Consistent with the in vitro data, CFZ treatment caused Caspase 3 cleavage in tumor cells from CFZ treatment group in vivo (Figure 6A). In addition, owing that some $\mathrm{N}$-myc amplified cell lines are more resistant to CFZ treatment compared to N-myc nonamplified cells, we tested whether CFZ could enhance the cytotoxic effects of Dox in N-myc amplified tumors in vivo. Using an orthotopic xenograft mouse model, we found that low dose of Dox ( $1 \mathrm{mg} / \mathrm{kg})$ or CFZ (3 mg/kg) treatment did not cause detectable PARP and Caspase 3 cleavages whereas combination treatment with both CFZ and Dox caused obvious PARP and Caspase 3 cleavages (Figure 6B). These results suggest that CFZ could

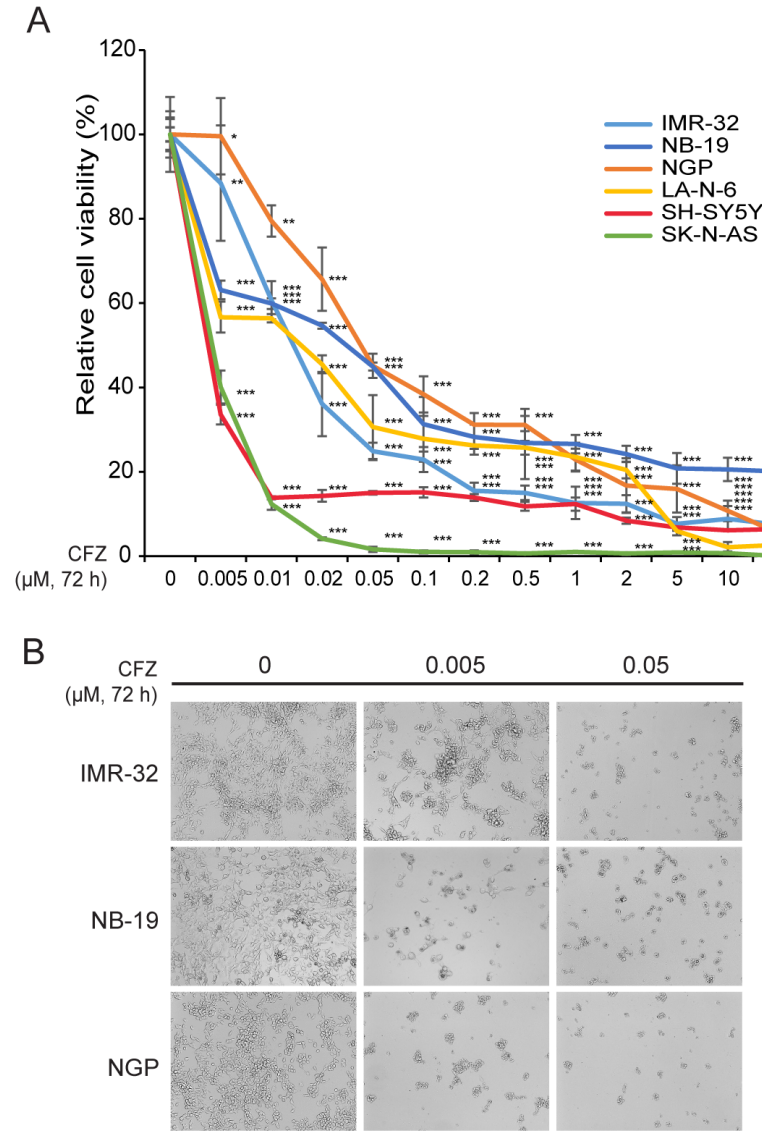

\begin{tabular}{cc}
\multicolumn{2}{c}{ IC50 of CFZ in NB cell lines } \\
\hline Cell lines & IC50 (nM) \\
\hline IMR-32 & 7.68 \\
NB-19 & 48.64 \\
NGP & 16.52 \\
LA-N-6 & 12.29 \\
SH-SY5Y & 3.31 \\
SK-N-AS & 5.50 \\
\hline
\end{tabular}

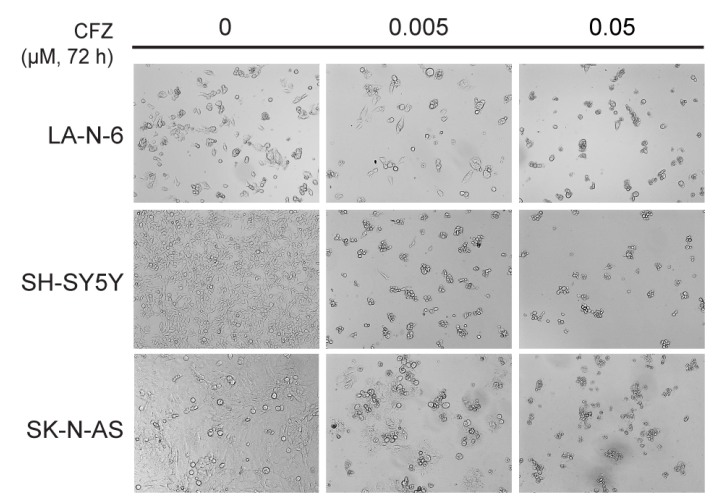

Figure 1: CFZ shows cytotoxic effect on a panel of six NB cells. A. Six NB cell lines were treated with increasing concentrations $(0 \mu \mathrm{M}, 0.005 \mu \mathrm{M}, 0.01 \mu \mathrm{M}, 0.02 \mu \mathrm{M}, 0.05 \mu \mathrm{M}, 0.1 \mu \mathrm{M}, 0.2 \mu \mathrm{M}, 0.5 \mu \mathrm{M}, 1 \mu \mathrm{M}, 2 \mu \mathrm{M}, 5 \mu \mathrm{M}, 10 \mu \mathrm{M}, 20 \mu \mathrm{M})$ of CFZ for $72 \mathrm{~h}$. Cell viability was assessed by CCK-8 assay. $P<0.05(*), P<0.01(* *)$, or $P<0.001(* * *)$ (Student's $t$-test, two-tailed) as indicated. The IC50 values of CFZ in each cell line listed were calculated in Graphpad Prism 5 and based on the data collected in the cell viability assay. B. Morphological changes of the six different NB cell lines treated with increasing concentrations $(0 \mu \mathrm{M}, 0.005 \mu \mathrm{M}, 0.05 \mu \mathrm{M})$ of CFZ for $72 \mathrm{~h}$ were shown. 
augment cytotoxic effects of Dox and enhance Doxinduced apoptosis in vivo.

\section{DISCUSSION}

Proteasome in the ubiquitin-proteasome system mediates the cellular polyubiquitination of substrate proteins and proteolytic degradation. The inhibition of proteasome promotes the accumulation of cellular proteins which results in the vulnerability of cancer cells [43]. Therefore, the proteasome inhibitor presents itself as a promising anticancer agent. According to prior studies, proteasome inhibitors, such as Bortezomib, Ixazomib [44, 45], and Carfilzomib [26] [46, 47] have demonstrated therapeutic efficacy in a variety of cancer types. CFZ, which is approved by the FDA for treating the relapsed and refractory multiple myeloma, proved to be tolerable with high efficacy and safety in solid tumors, including lung cancer, head and neck squamous cell carcinoma, and glioblastoma [46] [48, 49]. Although the evaluation of CFZ and its mechanism on $\mathrm{NB}$ remain unknown, we

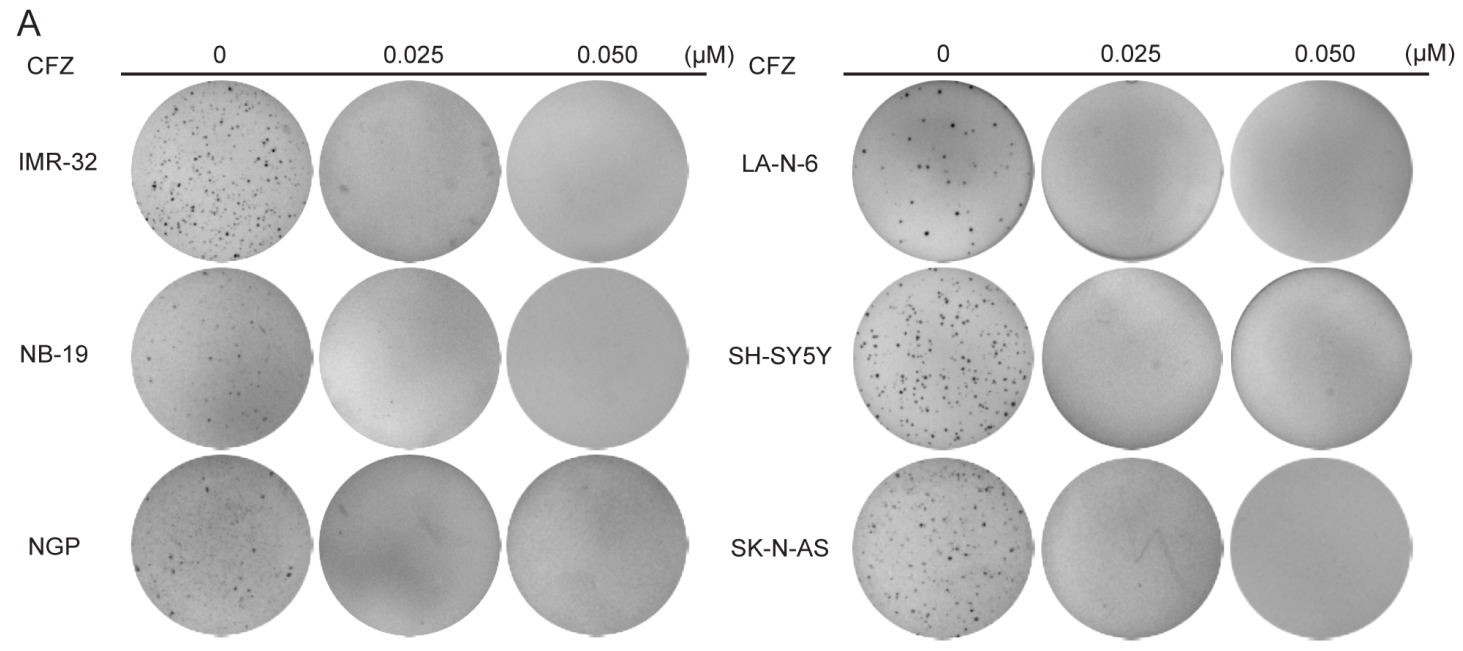

B
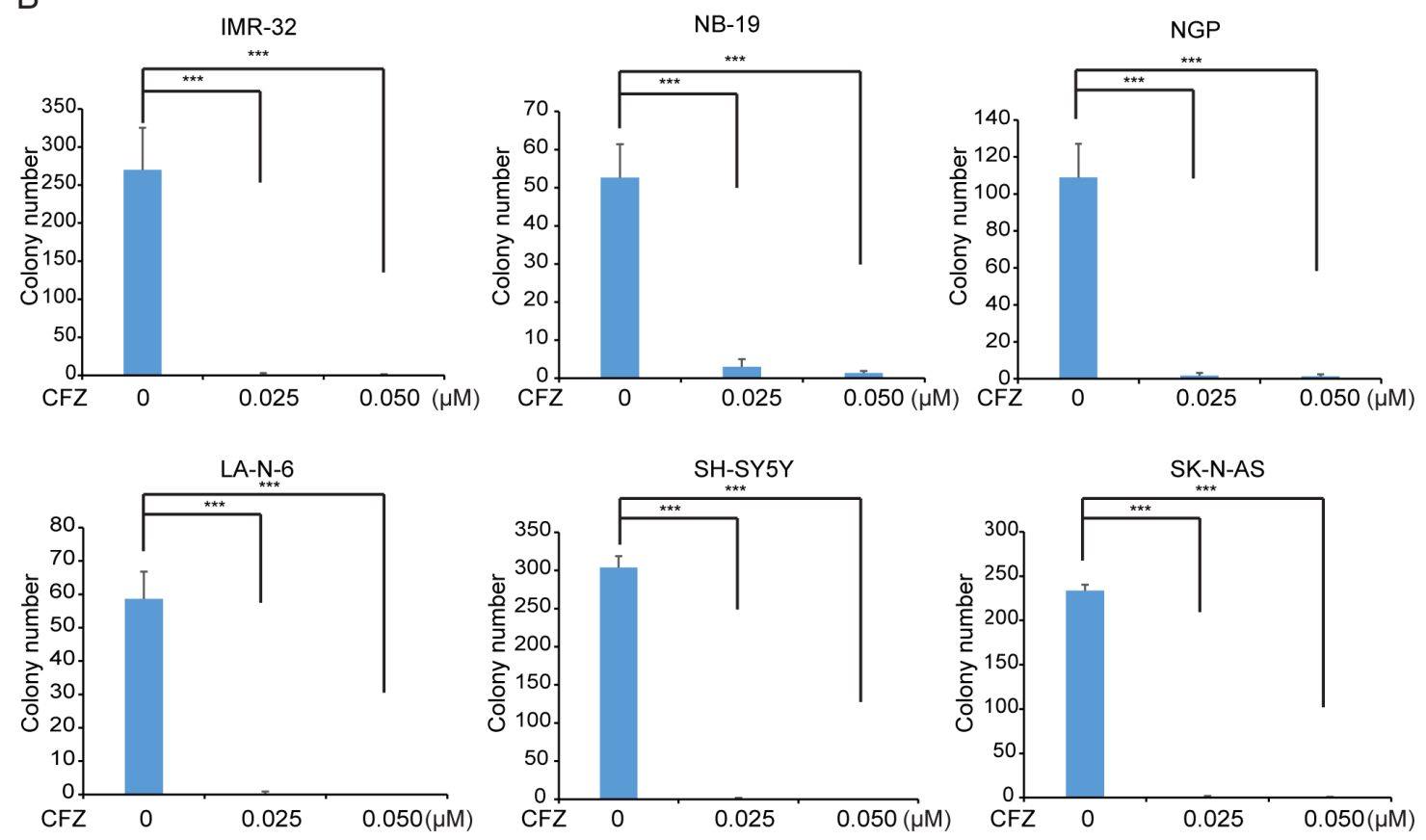

Figure 2: CFZ suppresses anchorage-independent growth of NB cells. A. A panel of six NB cell lines were seeded in six-well plates with indicated concentrations of CFZ and agar, and grown for 2 to 3 weeks. Cells were stained with crystal violet for $4 \mathrm{~h}$, and images were obtained. B. Colonies were counted and colony numbers were represented as mean $\pm \mathrm{SD}$ with $P<0.001(* * *)($ ANOVA, Dunnett) as indicated. 
hypothesize that CFZ might be an efficient and applicable anti-NB armamentarium.

Consistent with our hypothesis, we found that CFZ caused diminished cell proliferation and increased cell death in a panel of six NB cell lines, including LA$\mathrm{N}-6$, a well-known chemoresistant cell line. IC50 values for the tested cell lines treated with CFZ were all in the low nanomolar range (3.31 nM to $48.64 \mathrm{nM})$. This is similar to the reported CFZ IC50 values $(0.2 \mathrm{nM}$ to 99.4 $\mathrm{nM}$ ) in other solid tumor cell lines [46, 47]. In addition, the soft agar assay revealed that CFZ strongly inhibits an anchorage-independent growth of NB cell lines. These results suggest that CFZ alone inhibits NB cell proliferation. After substantiating CFZ's inhibitory effects on NB cell proliferation, we also found that CFZ induced apoptosis in NB in all six cell lines tested.

Another critical issue frequently raised in the clinical setting is the drug resistance of monotherapies [50]. To overcome the potential chemoresistance built by single drug treatment, the combination of different chemotherapies may be a better treatment option for patients. Dox has been widely used as an anti-cancer agent for many tumor types, while Dox is reported to associate with multiple damaging side effects, especially injury to the heart [16]. Thus, finding ways to enhance the intended anti-cancer effects of Dox is vitally important. We evaluated the combinatory effects of CFZ and traditional drug Dox on NB. Our results indicate that in comparison to Dox alone, the combination of lower dose of CFZ and Dox achieved greater inhibitory effect on NB cell proliferation and enhanced PARP and Caspase 3 cleavages in NB cells, suggesting that CFZ is able to efficiently enhance the Doxinduced apoptosis in tumor cells and combination of CFZ and Dox may allow to use lower dose of Dox to achieve a better treatment outcome for NB patients with less Doxcaused side effect.

$\mathrm{NF}-\kappa \mathrm{B}$ activity has been implicated in chemoresistance of NB [18, 51], and CFZ is reported to interfere with the NF- $\mathrm{kB}$ activation in other cancer types. Since Dox serves as a strong NF- $\mathrm{kB}$ inducer and has been shown to activate NF- $\mathrm{KB}$ signal pathway in cancer cells [16], we tested whether CFZ could inhibit Dox-induced NF- $\mathrm{\kappa B}$ activation in NB cells. Our results indicate that CFZ could inhibit Dox-induced NF-KB activation by
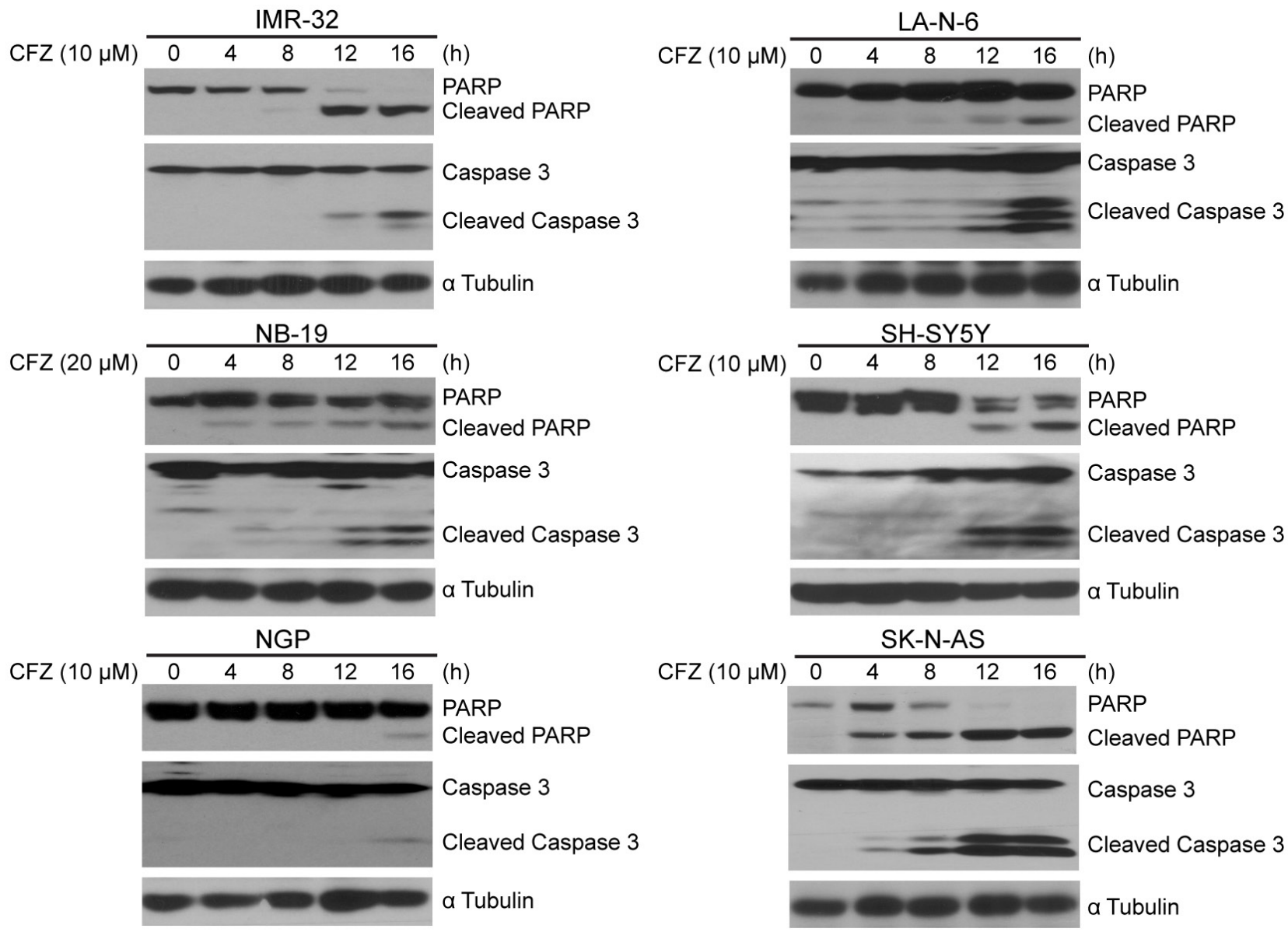

Figure 3: CFZ induces apoptosis of NB cells. A panel of six cell lines were treated with 10 or $20 \mu \mathrm{M}$ of CFZ for $0 \mathrm{~h}, 4 \mathrm{~h}, 8 \mathrm{~h}, 12 \mathrm{~h}$ or $16 \mathrm{~h}$, subjected to SDS-PAGE, and then immunoblotted with anti-PARP, anti-Caspase 3, and anti- $\alpha$ Tubulin antibodies. 
stabilizing I $\kappa \mathrm{B} \alpha$ in NB cells. In addition, CFZ enhanced Dox-induced p38 and JNK phosphorylation. It is reported that p38 and JNK may mediate apoptotic pathway [52]. We reason that CFZ might enhance proteasome inhibitioninduced cytotoxic stimuli and further counterbalance cellular homeostasis, which in turn stimulates higher phosphorylation and activation of p38 and JNK pathway.
On the other hand, the CFZ-mediated inhibition of NF$\kappa \mathrm{B}$ activation might inhibit cell survival and enhance the efficacy of chemotherapy.

Moreover, CFZ showed anti-tumor efficacy in an orthotopic xenograft NB mouse model, since a relatively low concentration of CFZ $(7.2 \mathrm{mg} / \mathrm{kg})$ could induce apoptosis in N-myc non-amplified NB cell line SH-
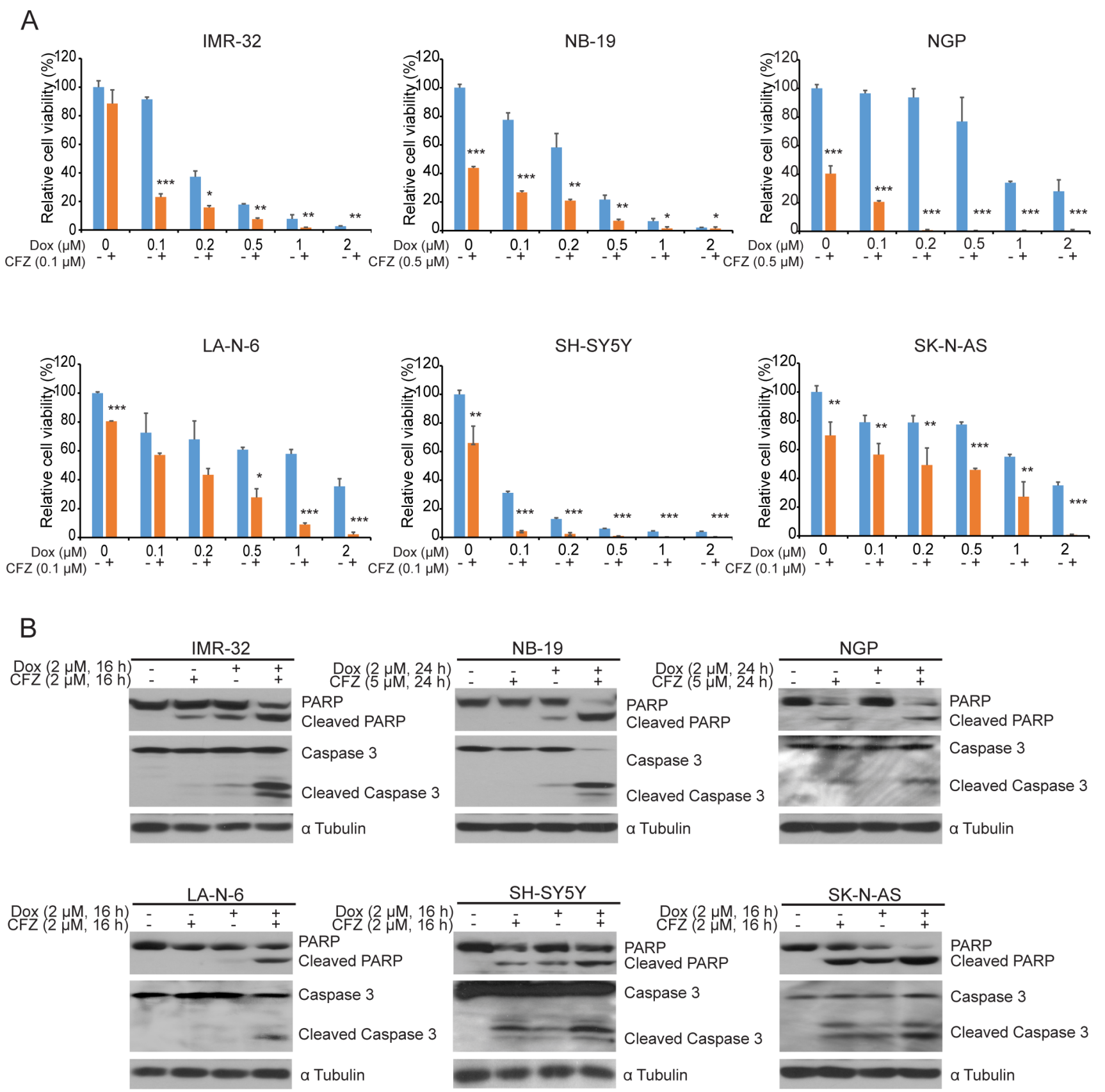

Figure 4: CFZ enhances the cytotoxic effect of Dox on NB cells. A. Six NB cell lines were treated with increasing concentrations of Dox or combined with CFZ $(0.1 \mu \mathrm{M}$ or $0.5 \mu \mathrm{M})$ for $48 \mathrm{~h}$. Cell viability was assessed by CCK-8 assay with $P<0.05(*), P<0.01(* *)$, or

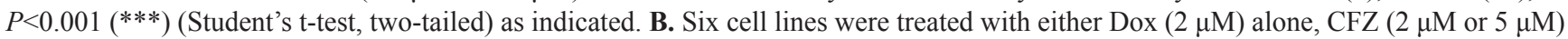
alone, or a combination of both for a fixed $16 \mathrm{~h}$. Then, they were subjected to SDS-PAGE and immunoblotted for anti-PARP, and antiCaspase 3 antibodies. The anti- $\alpha$ Tubulin antibody was used as a loading control for whole cell extracts in all samples. 

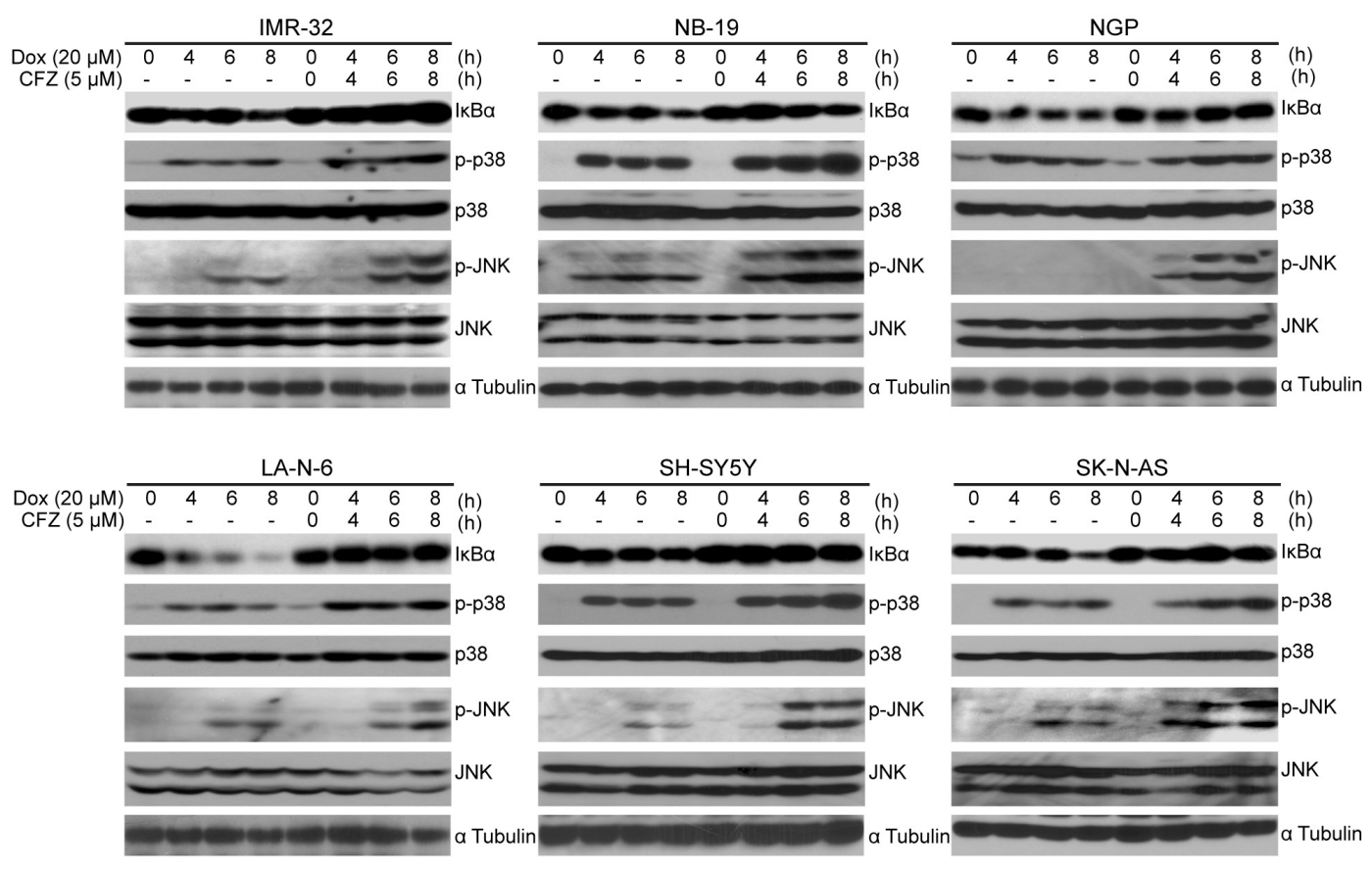

Figure 5: CFZ inhibits Dox-induced IKBa degradation and enhances Dox-induced p38 and JNK phosphorylation in NB cells. A panel of six cell lines were treated with $20 \mu \mathrm{M}$ of Dox or the combination of $10 \mu \mathrm{M} \mathrm{CFZ}$ and $20 \mu \mathrm{M}$ Dox for $0 \mathrm{~h}, 4 \mathrm{~h}, 6 \mathrm{~h}$ or $8 \mathrm{~h}$ points, subjected to SDS-PAGE, and then immunoblotted with anti-I $\mathrm{B} \mathrm{B} \alpha$, anti-p-p38, anti-p38, anti-p-JNK, anti-JNK and anti- $\alpha$ tubulin antibodies.

A

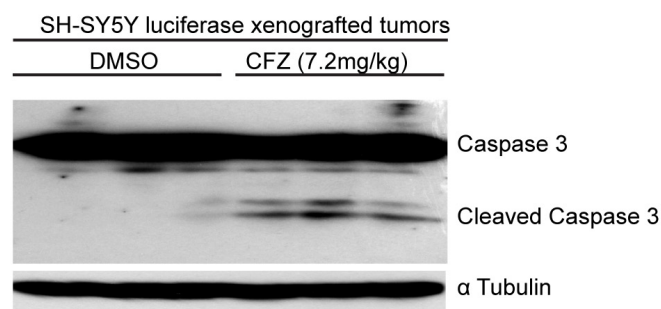

B

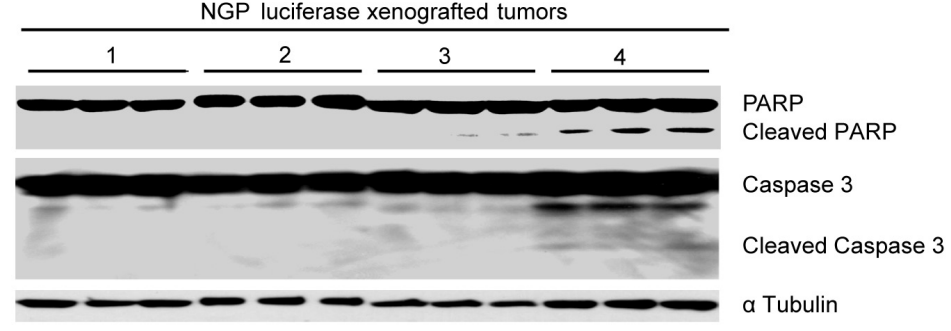
1. DMSO
2. $\mathrm{CFZ}(3 \mathrm{mg} / \mathrm{kg})$
3. Dox (1 mg/kg)
4. CFZ (3 mg/kg) + Dox (1 mg/kg)

Figure 6: CFZ induces apoptosis in an orthotopic xenograft mouse model of NB. A. The nude mice bearing SH-SY5Y NB cells were treated with DMSO or $7.2 \mathrm{mg} / \mathrm{kg}$ of CFZ (intraperitoneal injection) daily for 3 days. Then, the tumors were harvested and subjected to SDS-PAGE and immunoblotted for detecting Caspase 3 cleavage. The anti- $\alpha$ Tubulin antibodies was used as a loading control for whole cell extracts. B. The nude mice bearing NGP cells were treated with DMSO, $3 \mathrm{mg} / \mathrm{kg}$ of CFZ, $1 \mathrm{mg} / \mathrm{kg}$ Dox, and the combination of CFZ (3 mg/kg) and Dox $(1 \mathrm{mg} / \mathrm{kg})$ daily for 3 days, respectively. Then, the tumors were harvested and subjected to SDS-PAGE and immunoblotted for detecting PARP and Caspase 3 cleavages. The anti- $\alpha$ Tubulin antibodies was used as a loading control for whole cell extracts. 
SY5Y in vivo. Some N-myc amplified cell lines are more resistant to $\mathrm{CFZ}$ treatment. In this case, it is likely that combination of CFZ and Dox could be a better strategy to treat N-myc amplified NB in vivo.

In summary, our results demonstrate that CFZ showed cytotoxic effects on NB by inducing apoptosis both in vitro and in vivo. Moreover, CFZ augmented Dox-induced cytotoxicity by enhancing Dox-induced p38 and JNK phosphorylation in a subset of NB cells. CFZ also overcome the chemoresistance of NB cells by stabilizing the protein level of I $\mathrm{B} \alpha$ and decreased Doxinduced NF- $\kappa \mathrm{B}$ activity. The evaluation of proteasome inhibitor CFZ in NB sheds light on CFZ as a potential anti-NB armamentarium in combination with current chemotherapy.

\section{MATERIALS AND METHODS}

\section{Antibodies and reagents}

Anti-PARP (9532), anti-Caspase 3 (9662), antiIкB $\alpha$ (9242), anti-phospho-p38 (9211), anti-p38 (9212), anti-phospho-JNK (9251), anti-JNK (9252), anti-mouse (7076) and anti-rabbit (7074) antibodies were from Cell Signaling Technology (Danvers, MA, USA); and anti- $\alpha$ Tubulin (10D8) (sc-53646) was from Santa Cruz Biotechnology (Dallas, TX, USA). CFZ was purchased from LC Laboratories (Woburn, MA, USA). Doxorubicin (D1515) was from Sigma-Aldrich Corp (St. Louis, MO, USA).

\section{Cell lines and cell culture}

The human NB cell lines (IMR-32, NB-19, NGP, LA-N-6, SH-SY5Y and SK-N-AS) were cultured in RPMI 1640 medium (Lonza, Walkersville, MD, USA), supplemented with $20 \%$ or $10 \%(\mathrm{v} / \mathrm{v})$ heat-inactivated Fetal Bovine Serum (FBS) (SAFC Biosciences, Lenexa, $\mathrm{KS}$, USA), 100 units $/ \mathrm{mL}$ penicillin, and $100 \mu \mathrm{g} / \mathrm{mL}$ streptomycin. All cells were maintained in a humidified incubator at a constant temperature of $37{ }^{\circ} \mathrm{C} \& 5 \%$ $\mathrm{CO}_{2}$. SH-SY5Y cell line with luciferase expression was generated with transduction of lentiviral luciferase virus containing a neo selectable marker, and then selected with G418800 $\mu \mathrm{g} / \mathrm{ml}$ (Enzo Life Sciences, Farmingdale, NY, USA) for 10 days. All experiments were performed with indicated protocol [53].

\section{Cell viability assay}

Cell viability was calculated using the Cell Counting Kit-8 (WST-8[2-(2-methoxy-4-nitrophenyl)-3(4-nitrophenyl)-5-(2, 4-disulfophenyl)-2H-tetrazolium, monosodium salt]) (Dojindo Laboratories, Rockville, MA, USA). Cells were plated and grown in 96-well clearbottom plates starting at $5 \times 10^{3}$ cells/well. After $24 \mathrm{~h}$ of incubation, increasing concentrations of CFZ, Dox, or a combination of both were added to the wells and the cells were then incubated for another $48 \mathrm{~h}$ or $72 \mathrm{~h}$. Then, a mixture of $10 \mu \mathrm{L}$ of CCK- 8 and $190 \mu \mathrm{L}$ of medium with $10 \%$ or $20 \%$ FBS was added into each well respectively. After $1 \mathrm{~h}$ of incubation, the absorbance was measured at $450 \mathrm{~nm}$ using a microplate reader. Each experiment was performed in replicates of six and background reading of the medium was subtracted from each well to standardize the results.

\section{Cell imaging}

A total of six NB cell lines (IMR-32, NB-19, NGP, LA-N-6, SH-SY5Y and SK-N-AS) were seeded in 96well plates at appropriate concentrations [53]. After $72 \mathrm{~h}$ of treatment with indicated concentrations $(0 \mu \mathrm{M}, 0.005$ $\mu \mathrm{M}, 0.05 \mu \mathrm{M})$ of CFZ, cell morphologies were observed and captured using an optical microscope.

\section{Colony formation assay}

The soft agar assay for detecting colony formation abilities was performed as previously described [54]. A 5\% $(\mathrm{w} / \mathrm{v})$ base agar layer was made by adding agar (214220, Difco Laboratories, Detroit, MI, USA) into distilled water and then the mixture were autoclaved for $50 \mathrm{~min}$ before cooling in a $56{ }^{\circ} \mathrm{C}$ water bath. This solution was then mixed with medium and to a final concentration of $0.5 \%$. To make the bottom agar layer, $2 \mathrm{~mL}$ of the $0.5 \%$ agar/ medium solution were added to each well and cooled until semi-solid. The top agar layer was made of $0.3 \%$ agar 1.5 $\mathrm{mL}$ and each NB cell line was counted and added to the mixture at $1.5 \times 10^{4}$ cells/well along with the indicated concentrations of CFZ. Cells were grown at $37{ }^{\circ} \mathrm{C}$ for 2 to 3 weeks, then stained with $500 \mu \mathrm{L}$ of $0.005 \%$ crystal violet (C3886, Sigma) for $4 \mathrm{~h}$. Images were captured by the microscope, and colonies were counted [53]. Each assay was performed in triplicate.

\section{Immunoblotting assay}

After each treatment, NB cells were washed twice with ice cold PBS. We collected cell pellets after centrifuging for $5 \mathrm{~min}$ at $6,000 \mathrm{rpm}$ and then lysed on a rotator at $4^{\circ} \mathrm{C}$ for $30 \mathrm{~min}$ in cooled RIPA buffer $(150$ $\mathrm{mM} \mathrm{NaCl}, 50 \mathrm{mM}$ Tris- $\mathrm{HCl}$ at $\mathrm{pH}$ 7.4, $50 \mathrm{mM}$ sodium fluoride, $1 \mathrm{mM}$ EDTA, $1 \mathrm{mM}$ dithiothreitol, $1 \mathrm{mM}$ phenylmethylsulfonyl fluoride, $1 \mathrm{mM}$ benzamidine, 0.1 $\mathrm{mM}$ sodium orthovanadate, $10 \mu \mathrm{g} / \mathrm{mL}$ leupeptin, $1 \%$ NP-40, $0.25 \%$ sodium deoxycholate, and phosphatase inhibitor cocktail 2 and 3 (p5726 and p0044, Sigma)). Then followed by centrifuging for $15 \mathrm{~min}$ at 13,000 rpm to collect supernatants as cell lysates. Protein concentration in cell lysates was measured using Bradford reagent (Bio-Rad Laboratories, Hercules, 
CA, USA), and samples were mixed with $4 \times$ loading buffer, respectively, and heated at $100{ }^{\circ} \mathrm{C}$ for $6 \mathrm{~min}$. Lysates were separated by SDS-PAGE, transferred to polyvinylidence fluoride (PVDF) membranes (BioRad), blocked with $5 \%$ milk for $1 \mathrm{~h}$ at room temperature $\left(25^{\circ} \mathrm{C}\right)$, and probed with appropriate dilutions of indicated primary antibodies overnight at $4^{\circ} \mathrm{C}$. The membranes were then incubated with anti-mouse or rabbit IgG conjugated with horseradish peroxidase at room temperature for $1 \mathrm{~h}$. The ECL-Plus Western detection system (GE Health Care, Buckinghamshire, UK) was then used for chemiluminescent visualization. The anti- $\alpha$ tubulin antibodies were used as a loading control for whole cell extracts in all samples.

\section{Antitumor efficacy in an orthotopic xenograft NB mouse model}

Four to six-week-old female athymic NCR nude mice were purchased from Taconic (Hudson, NY, USA) and maintained under barrier conditions (pathogenfree conditions provided by plastic cages with sealed air filters). The preclinical mouse model of NB was established using orthotopic (intrarenal) implantation of the NB cells as described previously $[53,54]$. Briefly, a transverse incision was created over the left flank of the nude mouse and $1.5 \times 10^{6}$ human luciferasetransduced SH-SY5Y cells (N-myc non-amplified cells) and luciferase-transduced NGP cells (N-myc amplified cells) in $0.1 \mathrm{ml}$ of PBS were surgically injected into the left renal capsule and toward the superior pole of the left kidney of the nude mice.

After engrafting for 5 to 6 weeks, mice bearing tumors with similar sizes (using bioluminescent imaging to monitor tumor growth) were randomly divided and treated with either DMSO or CFZ $(7.2 \mathrm{mg} / \mathrm{kg}$, intraperitoneal injection daily). For combination therapy, mice bearing tumors were treated with DMSO, CFZ (3 mg/kg), Dox (1 $\mathrm{mg} / \mathrm{kg}$ ) and CFZ (3 mg/kg) + Dox (1 mg/kg) every day. Three days later, the mice were sacrificed and the tumors were harvested and lysed for immunoblotting analysis. All mice were handled according to protocols approved by the Institutional Animal Care and Use Committee of the Baylor College of Medicine.

\section{Statistical Analysis}

All values were presented as mean \pm standard deviation (SD). A two-tailed Student's $t$-test and ANOVA were used to determine the statistical significance among drug treatment group and control group. Each assay was repeated at least twice, and representative results were presented. $P<0.05$ was considered to be statistically significant. The IC50 value was calculated by Graphpad Prism 5 software (La Jolla, CA, USA).

\section{Abbreviations}

NB, neuroblastoma; CFZ, Carfilzomib; Dox, doxorubicin; DMSO, dimethyl sulfoxide; FDA, US Food and Drug Administration; NF- $\kappa \mathrm{B}$, the transcriptional factor nuclear factor kappa $\mathrm{B}$; I $\mathrm{I} \mathrm{B} \alpha$, the nuclear factor of kappa light polypeptide gene enhancer in B-cells inhibitor, alpha; PARP, poly ADP ribose polymerase.

\section{ACKNOWLEDGMENTS}

We thank Dr. Andrew Davidoff (St. Judes's Children's Research Hospital, Memphis, TN, USA) and Dr. Robert Seeger (Children's Hospital of Los Angeles, Los Angeles, CA, USA) for providing the human NB cell lines used in this paper. Xinfang Mao is a recipient of a China Scholarship Council training grant (No.201408655087) and Zhenghu Chen is a recipient of the Tongji University International Exchange Award.

\section{CONFLICTS OF INTEREST}

The authors declare no competing financial interests.

\section{GRANT SUPPORT}

This work was supported by the NIH-NINDS grants to J.Y. (1R01NS072420, 1R21NS085467 and 1R21NS094654).

\section{REFERENCES}

1. Louis CU, Shohet JM. Neuroblastoma: molecular pathogenesis and therapy. Annual review of medicine. 2015; 66:49-63.

2. Maris JM. Recent advances in neuroblastoma. The New England journal of medicine. 2010; 362:2202-2211.

3. Bowen KA, Chung DH. Recent advances in neuroblastoma. Current opinion in pediatrics. 2009; 21:350-356.

4. Peters JM, Franke WW, Kleinschmidt JA. Distinct 19 S and $20 \mathrm{~S}$ subcomplexes of the $26 \mathrm{~S}$ proteasome and their distribution in the nucleus and the cytoplasm. The Journal of biological chemistry. 1994; 269:7709-7718.

5. Aquilano K, Rotilio G, Ciriolo MR. Proteasome activation and nNOS down-regulation in neuroblastoma cells expressing a $\mathrm{Cu}, \mathrm{Zn}$ superoxide dismutase mutant involved in familial ALS. Journal of neurochemistry. 2003; 85:1324-1335.

6. Archer CR, Koomoa DL, Mitsunaga EM, Clerc J, Shimizu M, Kaiser M, Schellenberg B, Dudler R, Bachmann AS. Syrbactin class proteasome inhibitor-induced apoptosis and autophagy occurs in association with p53 accumulation and $\mathrm{Akt} / \mathrm{PKB}$ activation in neuroblastoma. Biochemical pharmacology. 2010; 80:170-178. 
7. Kyratzi E, Pavlaki M, Kontostavlaki D, Rideout HJ, Stefanis L. Differential effects of Parkin and its mutants on protein aggregation, the ubiquitin-proteasome system, and neuronal cell death in human neuroblastoma cells. Journal of neurochemistry. 2007; 102:1292-1303.

8. Caputi FF, Carboni L, Mazza D, Candeletti S, Romualdi P. Cocaine and ethanol target $26 \mathrm{~S}$ proteasome activity and gene expression in neuroblastoma cells. Drug Alcohol Depend. 2016; 161:265-275.

9. Wang Z, Aris VM, Ogburn KD, Soteropoulos P, FigueiredoPereira ME. Prostaglandin J2 alters pro-survival and prodeath gene expression patterns and $26 \mathrm{~S}$ proteasome assembly in human neuroblastoma cells. J Biol Chem. 2006; 281:21377-21386.

10. Huseby NE, Ravuri C, Moens U. The proteasome inhibitor lactacystin enhances GSH synthesis capacity by increased expression of antioxidant components in an Nrf2-independent, but p38 MAPK-dependent manner in rat colorectal carcinoma cells. Free radical research. 2016; 50:1-13.

11. Infante JR, Mendelson DS, Burris HA3rd, Bendell JC, Tolcher AW, Gordon MS, Gillenwater HH, Arastu-Kapur S, Wong HL, Papadopoulos KP. A first-in-human doseescalation study of the oral proteasome inhibitor oprozomib in patients with advanced solid tumors. Investigational new drugs. 2016; 34:216-224.

12. Khan T, Stauffer JK, Williams R, Hixon JA, Salcedo R, Lincoln E, Back TC, Powell D, Lockett S, Arnold AC, Sayers TJ, Wigginton JM. Proteasome inhibition to maximize the apoptotic potential of cytokine therapy for murine neuroblastoma tumors. Journal of immunology. 2006; 176:6302-6312.

13. Kumar B, Hanson AJ, Prasad KN. Sensitivity of proteasome to its inhibitors increases during cAMP-induced differentiation of neuroblastoma cells in culture and causes decreased viability. Cancer letters. 2004; 204:53-59.

14. Luo P, Lin M, Li L, Yang B, He Q. The proteasome inhibitor bortezomib enhances ATRA-induced differentiation of neuroblastoma cells via the JNK mitogen-activated protein kinase pathway. PloS one. 2011; 6:e27298.

15. Hammerle B, Yanez Y, Palanca S, Canete A, Burks DJ, Castel V, Font de Mora J. Targeting neuroblastoma stem cells with retinoic acid and proteasome inhibitor. PloS one. 2013; 8:e76761.

16. Tacar O, Sriamornsak P, Dass CR. Doxorubicin: an update on anticancer molecular action, toxicity and novel drug delivery systems. The Journal of pharmacy and pharmacology. 2013; 65:157-170.

17. Yang HJ, Wang M, Wang L, Cheng BF, Lin XY, Feng ZW. NF-kappaB regulates caspase-4 expression and sensitizes neuroblastoma cells to Fas-induced apoptosis. PloS one. 2015; 10:e117953.
18. Mitchell S, Vargas J, Hoffmann A. Signaling via the NFkappaB system. Wiley interdisciplinary reviews Systems biology and medicine. 2016; 8:227-241.

19. Yousefi M, Ghaffari SH, Soltani BM, Nafissi S, Momeny M, Zekri A, Behmanesh M, Alimoghaddam K, Ghavamzadeh A. Therapeutic efficacy of silibinin on human neuroblastoma cells: Akt and NF-kappaB expressions may play an important role in silibinin-induced response. Neurochemical research. 2012; 37:2053-2063.

20. Forloni M, Albini S, Limongi MZ, Cifaldi L, Boldrini R, Nicotra MR, Giannini G, Natali PG, Giacomini P, Fruci D. NF-kappaB, and not MYCN, regulates MHC class I and endoplasmic reticulum aminopeptidases in human neuroblastoma cells. Cancer research. 2010; 70:916-924.

21. Galenkamp KM, Carriba P, Urresti J, Planells-Ferrer L, Coccia E, Lopez-Soriano J, Barneda-Zahonero B, Moubarak RS, Segura MF, Comella JX. TNFalpha sensitizes neuroblastoma cells to FasL-, cisplatin- and etoposide-induced cell death by NF-kappaB-mediated expression of Fas. Molecular cancer. 2015; 14:62.

22. Hewson QD, Lovat PE, Corazzari M, Catterall JB, Redfern CP. The NF-kappaB pathway mediates fenretinide-induced apoptosis in SH-SY5Y neuroblastoma cells. Apoptosis. 2005; 10:493-498.

23. Wang L, Cheng BF, Yang HJ, Wang M, Feng ZW. NF-kappaB protects human neuroblastoma cells from nitric oxide-induced apoptosis through upregulating biglycan. American journal of translational research. 2015; 7:1541-1552.

24. Pordanjani SM, Hosseinimehr SJ. The role of NF-kB inhibitors in cell response to radiation. Curr Med Chem. 2016.

25. Brown RE, Tan D, Taylor JS, Miller M, Prichard JW, Kott MM. Morphoproteomic confirmation of constitutively activated mTOR, ERK, and NF-kappaB pathways in high risk neuro-blastoma, with cell cycle and protein analyte correlates. Ann Clin Lab Sci. 2007; 37:141-147.

26. Armstrong MB, Schumacher KR, Mody R, Yanik GA, Opipari AW, Jr. and Castle VP. Bortezomib as a therapeutic candidate for neuroblastoma. Journal of experimental therapeutics \& oncology. 2008; 7:135-145.

27. Luo P, Lin M, Lin M, Zhu D, Wang Z, Shen J, Yang B, He Q. Bortezomib induces apoptosis in human neuroblastoma CHP126 cells. Die Pharmazie. 2010; 65:213-218.

28. Chauhan D, Tian Z, Zhou B, Kuhn D, Orlowski R, Raje N, Richardson $\mathrm{P}$, Anderson KC. In vitro and in vivo selective antitumor activity of a novel orally bioavailable proteasome inhibitor MLN9708 against multiple myeloma cells. Clinical cancer research. 2011; 17:5311-5321.

29. Garcia-Gomez A, Quwaider D, Canavese M, Ocio EM, Tian Z, Blanco JF, Berger AJ, Ortiz-de-Solorzano C, HernandezIglesias T, Martens AC, Groen RW, Mateo-Urdiales J, Fraile $\mathrm{S}$, et al. Preclinical activity of the oral proteasome 
inhibitor MLN9708 in Myeloma bone disease. Clinical cancer research. 2014; 20:1542-1554.

30. Gupta SV, Hertlein E, Lu Y, Sass EJ, Lapalombella R, Chen TL, Davis ME, Woyach JA, Lehman A, Jarjoura D, Byrd JC, Lucas DM. The proteasome inhibitor carfilzomib functions independently of p53 to induce cytotoxicity and an atypical NF-kappaB response in chronic lymphocytic leukemia cells. Clinical cancer research. 2013; 19:2406-2419.

31. Levin N, Spencer A, Harrison SJ, Chauhan D, Burrows FJ, Anderson KC, Reich SD, Richardson PG, Trikha M. Marizomib irreversibly inhibits proteasome to overcome compensatory hyperactivation in multiple myeloma and solid tumour patients. British journal of haematology. 2016.

32. Zhang XD, Baladandayuthapani V, Lin H, Mulligan G, Li B, Esseltine DW, Qi L, Xu J, Hunziker W, Barlogie B, Usmani SZ, Zhang Q, Crowley J, et al. Tight Junction Protein 1 Modulates Proteasome Capacity and Proteasome Inhibitor Sensitivity in Multiple Myeloma via EGFR/JAK1/ STAT3 Signaling. Cancer cell. 2016; 29:639-652.

33. Wang X, Ibrahim YF, Das D, Zungu-Edmondson M, Shults NV, Suzuki YJ. Carfilzomib reverses pulmonary arterial hypertension. Cardiovascular research. 2016; 110:188-199.

34. Zhang L, Boufraqech M, Lake R, Kebebew E. Carfilzomib potentiates CUDC-101-induced apoptosis in anaplastic thyroid cancer. Oncotarget. 2016; 7:16517-28. doi: 10.18632/oncotarget.7760.

35. Watanabe $T$, Tobinai $K$, Matsumoto M, Suzuki K, Sunami K, Ishida T, Ando K, Chou T, Ozaki S, Taniwaki M, Uike N, Shibayama H, Hatake K, et al. A phase 1/2 study of carfilzomib in Japanese patients with relapsed and/or refractory multiple myeloma. British journal of haematology. 2016; 172:745-756.

36. Wartman LD, Fiala MA, Fletcher T, Hawkins ER, Cashen A, DiPersio JF, Jacoby MA, Stockerl-Goldstein KE, Pusic I, Uy GL, Westervelt P, Vij R. A phase I study of carfilzomib for relapsed or refractory acute myeloid and acute lymphoblastic leukemia. Leukemia \& lymphoma. 2016; 57:728-730.

37. Perel G, Bliss J, Thomas CM. Carfilzomib (Kyprolis): A Novel Proteasome Inhibitor for Relapsed And/or Refractory Multiple Myeloma. P \& T. 2016; 41:303-307.

38. Rosebeck S, Alonge MM, Kandarpa M, Mayampurath A, Volchenboum SL, Jasielec J, Dytfeld D, Maxwell SP, Kraftson SJ, McCauley D, Shacham S, Kauffman M, Jakubowiak AJ. Synergistic Myeloma Cell Death via Novel Intracellular Activation of Caspase-10-Dependent Apoptosis by Carfilzomib and Selinexor. Molecular cancer therapeutics. 2016; 15:60-71.

39. Sestak V, Roh J, Klepalova L, Kovarikova P. A UHPLCUV-QTOF study on the stability of carfilzomib, a novel proteasome inhibitor. Journal of pharmaceutical and biomedical analysis. 2016; 124:365-373.

40. Hanke NT, Garland LL, Baker AF. Carfilzomib combined with suberanilohydroxamic acid (SAHA) synergistically promotes endoplasmic reticulum stress in non-small cell lung cancer cell lines. Journal of cancer research and clinical oncology. 2016; 142:549-560.

41. Lamothe B, Wierda W, Keating MJ, Gandhi V. Carfilzomib triggers cell death in chronic lymphocytic leukemia by inducing proapoptotic and endoplasmic reticulum stress responses. Clinical cancer research. 2016.

42. Ulbrich F, Lerach T, Biermann J, Kaufmann KB, Lagreze WA, Buerkle H, Loop T, Goebel U. Argon mediates protection by Interleukin-8 suppression via a TLR2/TLR4/ STAT3/NF-kappaB pathway in a model of apoptosis in neuroblastoma cells in-vitro and following ischemiareperfusion injury in rat retina in-vivo. Journal of neurochemistry. 2016.

43. Johnson DE. The ubiquitin-proteasome system: opportunities for therapeutic intervention in solid tumors. Endocrine-related cancer. 2015; 22:T1-17.

44. Muz B, Ghazarian RN, Ou M, Luderer MJ, Kusdono HD, Azab AK. Spotlight on ixazomib: potential in the treatment of multiple myeloma. Drug design, development and therapy. 2016; 10:217-226.

45. Offidani M, Corvatta L, Gentili S, Maracci L, Leoni P. Oral ixazomib maintenance therapy in multiple myeloma. Expert review of anticancer therapy. 2016; 16:21-32.

46. Baker AF, Hanke NT, Sands BJ, Carbajal L, Anderl JL, Garland LL. Carfilzomib demonstrates broad anti-tumor activity in pre-clinical non-small cell and small cell lung cancer models. Journal of experimental \& clinical cancer research. 2014; 33:111.

47. Mehta A, Zhang L, Boufraqech M, Zhang Y, Patel D, Shen M, Kebebew E. Carfilzomib is an effective anticancer agent in anaplastic thyroid cancer. Endocrine-related cancer. 2015; 22:319-329.

48. Zang Y, Kirk CJ, Johnson DE. Carfilzomib and oprozomib synergize with histone deacetylase inhibitors in head and neck squamous cell carcinoma models of acquired resistance to proteasome inhibitors. Cancer biology \& therapy. 2014; 15:1142-1152.

49. Booth L, Cruickshanks N, Tavallai S, Roberts JL, Peery M, Poklepovic A, Dent P. Regulation of dimethyl-fumarate toxicity by proteasome inhibitors. Cancer biology \& therapy. 2014; 15:1646-1657.

50. Yardley DA. Drug resistance and the role of combination chemotherapy in improving patient outcomes. International journal of breast cancer. 2013; 2013:137414.

51. Jakkampudi A, Jangala R, Reddy BR, Mitnala S, Reddy DN, Talukdar R. NF-kappaB in acute pancreatitis: Mechanisms and therapeutic potential. Pancreatology. 2016.

52. Cheng J, Fan YH, Xu X, Zhang H, Dou J, Tang Y, Zhong X, Rojas Y, Yu Y, Zhao Y, Vasudevan SA, Zhang H, Nuchtern $\mathrm{JG}$, et al. A small-molecule inhibitor of UBE2N induces neuroblastoma cell death via activation of p53 and JNK pathways. Cell Death Dis. 2014; 5:e1079. 
53. Wang Y, Wang L, Guan S, Cao W, Wang H, Chen Z, Zhao Y, Yu Y, Zhang H, Pang JC, Huang SL, Akiyama Y, Yang Y, Sun W, Xu X, Shi Y, et al. Novel ALK inhibitor AZD3463 inhibits neuroblastoma growth by overcoming crizotinib resistance and inducing apoptosis. Scientific reports. 2016; 6:19423.
54. Fan YH, Cheng J, Vasudevan SA, Dou J, Zhang H, Patel RH, Ma IT, Rojas Y, Zhao Y, Yu Y, Zhang H, Shohet JM, Nuchtern JG, et al. USP7 inhibitor P22077 inhibits neuroblastoma growth via inducing p53-mediated apoptosis. Cell death \& disease. 2013; 4:e867. 